\title{
13. Number of workers per family
}

\section{PART I. BACKGROUND AND CONCEPTUAL FRAMEWORK}

\subsection{More Than One Worker per Family}

Living wage is a family concept. It is therefore appropriate to expect more than one adult in a family to work and provide financial support for the family. For this reason, the cost of a decent living standard for a reference size family is assumed to be defrayed over the number of full-time equivalent workers in a family. The larger the number of full-time equivalent workers in the family, the smaller the living wage. The issue is not whether more than one person in a family should be expected to work, but how to determine the number of workers in a reference family. This chapter describes how to estimate the number of full-time equivalent workers in a reference family to use to estimate a living wage.

The 2011 ILO review of living wage methodologies (Anker, 2011) found that one worker per couple and two workers per couple have been the most common assumptions used in previous methodologies to estimate living wages. Neither of these assumptions is realistic or reasonable in today's world. The one worker (usually male) breadwinner model of the household which might have been the norm 50 to 100 years ago in Western countries is not relevant in many places in the world today. The other common assumption - that all adults work full-time - is equally unrealistic. In all countries, many adults who wish to work are unemployed or unable to find full-time work throughout the year. In addition, many adults work part-time because they have family care responsibilities. In our methodology, the number of full-time workers per family is always between one and two full-time equivalent workers. We have found that the range for the number of full-time equivalent workers per couple in our methodology tends to be between around 1.5 to around 1.9 (see Section 13.6.4). 


\subsection{Number of Workers per Family Needs to be Country- and Location-Specific}

There is large variation around the world in the extent to which women are in the labor force (with much less variation for men). Unemployment rates and the extent to which male and female workers are able to find full-time equivalent work throughout the year also vary around the world. Because of these variations, the number of full-time workers per family that can be expected to provide support needs to be country-specific, should usually differ between rural and urban areas in a country, and should be regionspecific in large countries.

\section{PART II. APPROACH TO DETERMINE THE NUMBER OF FULL-TIME EQUIVALENT WORKERS PER FAMILY}

This section describes how to estimate the number of full-time equivalent workers per couple who provide support. Estimates are based on three different statistics namely:

(i) labor force participation rate (LFPR),

(ii) unemployment rate (U), and

(iii) part-time employment rate and/or hours of work (PT).

Definitions, sources of information, and variation by important factors such as sex, age, and location, as well as possible pitfalls in the use of these data, are discussed in Sections 13.3 to 13.5. Equations used to estimate the number of full-time equivalent workers per family are presented in Section 13.6. Appendix 13.1 provides dummy tables to record secondary data for LFPR, U and PT.

\subsection{Labor Force Participation Rate (Probability of Being Economically Active)}

\subsubsection{Definition and measurement of labor force participation rate}

Labor force is the sum of the number of persons employed and the number of persons unemployed. The labor force participation rate is the ratio of the labor force to the working age population, expressed as a percentage (ILO, 1982). Thus, labor force participation rate provides an estimate of the probability that someone is either working/economically active or unemployed/looking for work. 
Before discussing variations in labor force participation rates by age, sex and region of the world, it is important to point out that labor force data are often subject to significant bias and error and so caution is needed when using data on labor force participation rates. It has been shown that measurement of labor force activity on surveys is very sensitive to how survey questions are asked and labor force is defined (Anker et al., 1987). There are important biases in the internationally accepted definition of work as regards unpaid family work. Typical work performed by women in or near home is often poorly measured in practice in surveys. For example, housework, care work, caring for small animals, firewood collection and water collection that are typically done by women are not usually considered as labor force activity in practice (Anker et al., 1987).

\subsubsection{Labor force participation rates differ by age}

Age-specific labor force participation rates typically display an inverted U shape. Rates increase from age 15 as youth leave school and join the labor force; rates are typically fairly stable from age 25 , especially for men, until later ages when rates decline as workers retire and leave the labor force. This means that labor force participation rates are much lower for youth (ages 15-24) than for adults ages 25+. For the world, the youth labor force participation rate (ages 15-24) is 48.5\% compared with $68.8 \%$ for adults ages $25+$. A large difference between youth and adult labor force participation rates is found in every region of the world (see Table 13.1). For this reason, we use labor force participation rates for persons 25-59 to estimate the number of full-time equivalent workers per couple. Ages 25-59 are prime working ages with family responsibilities. In contrast, many of those ages 15-24 have not yet joined the labor force because they are still in school, while many of those above age 60 have retired and left the labor force. Inclusion of those less than age 25 and those above age 60 would inappropriately reduce the estimated labor force participation rate used to estimate a living wage.

For this reason, in our methodology labor force participation rates are estimated for ages 25-59, data permitting.

\subsubsection{Labor force participation rates differ by gender}

Labor force participation rates (LFPR) are lower for women than for men throughout the world, because some or many women are out of the labor force in part because women are responsible for child care and care for the elderly throughout the world (Table 13.1). This is not only true for the world as a whole (LFPR is $83.7 \%$ for men ages $25+$ compared with $54.2 \%$ for women ages $25+$ ), but it is also true for every region in the world. 
Table 13.1 Labor force participation rates by age, sex and region, 2012

\begin{tabular}{|c|c|c|c|c|c|c|c|c|c|}
\hline \multirow[t]{2}{*}{ Region } & \multicolumn{3}{|l|}{ Male } & \multicolumn{3}{|c|}{ Female } & \multicolumn{3}{|l|}{ Total } \\
\hline & Adult & Youth & Total & Adult & Youth & Total & Adult & Youth & Total \\
\hline World & 83.7 & 56.1 & 77.1 & 54.2 & 40.5 & 51.1 & 68.8 & 48.5 & 64.1 \\
\hline Middle East & 84.7 & 46.5 & 74.3 & 21.0 & 13.2 & 18.7 & 55.0 & 30.3 & 48.1 \\
\hline North Africa & 85.1 & 46.8 & 74.3 & 26.1 & 19.7 & 24.4 & 55.1 & 33.4 & 49.1 \\
\hline South Asia & 90.7 & 57.3 & 81.3 & 35.0 & 23.4 & 31.8 & 63.4 & 41.0 & 57.1 \\
\hline $\begin{array}{l}\text { Latin America } \\
\text { and Caribbean }\end{array}$ & 85.3 & 62.1 & 79.5 & 57.0 & 42.7 & 53.6 & 70.7 & 52.5 & 66.3 \\
\hline $\begin{array}{l}\text { South-East Asia } \\
\text { and Pacific }\end{array}$ & 89.5 & 59.2 & 81.8 & 63.0 & 45.1 & 58.8 & 76.0 & 52.3 & 70.1 \\
\hline $\begin{array}{l}\text { Sub-Sahara } \\
\text { Africa }\end{array}$ & 87.4 & 55.9 & 76.3 & 71.5 & 51.4 & 64.6 & 70.4 & 53.6 & 70.4 \\
\hline East Asia & 84.7 & 58.8 & 79.4 & 67.7 & 61.1 & 66.4 & 76.3 & 59.8 & 73.1 \\
\hline $\begin{array}{l}\text { Central \& South- } \\
\text { East Europe }\end{array}$ & 76.2 & 49.6 & 70.7 & 53.6 & 34.1 & 50.2 & 63.9 & 42.0 & 59.8 \\
\hline $\begin{array}{l}\text { Developed } \\
\text { Economies \& } \\
\text { Europe }\end{array}$ & 70.9 & 49.2 & 67.5 & 54.0 & 45.3 & 52.8 & 62.2 & 47.3 & 60.0 \\
\hline
\end{tabular}

Notes: Youth is defined as ages $15-24$ and adults as ages $25+$. Labor force participation rates for ages $25-59$ are higher than for ages $25+$ because participation rates are lower at ages $60+$.

Source: ILO KILM, 2013a.

It is for this reason in our methodology that labor force participation rates for men and women are averaged to determine a participation rate for couples and families.

\subsubsection{Female labor force participation rates affected by cultural norms}

Labor force participation rates for adult males are fairly similar around the world, although they are lower for developed countries and Europe. ${ }^{1}$ In contrast, female labor force participation rates vary greatly by region along with cultural norms and acceptability of women working outside the home and family farm (Table 13.1). Regional adult female participation rates range from a low of around $20 \%$ to a high of around $70 \%$ - going from $20-25 \%$ in Middle East and North Africa; to around 35\% in South Asia; to around 63-68\% in South-East and East Asia and around 72\% in Sub-Saharan Africa.

For this reason, in our methodology, it is important to use countryspecific data on labor force participation and region-specific data in large and diverse countries such as India where there are large regional differences in female labor force participation. 


\subsubsection{Labor force participation rates differ in rural and urban areas}

Labor force participation rates are generally higher in rural areas than in urban areas in developing countries mainly because many women in rural areas work on a family farm or care for family-owned animals. This is why it is important to use rural and urban specific data on labor force participation.

\subsubsection{Child labor should be ignored}

Children often work and make important contributions to family income in developing countries. This possibility should not be considered when estimating a living wage, because child labor is not consistent with decency in the twenty-first century. This is another reason why labor force participation rates for young persons are not used to determine the number of workers per family in our methodology.

\subsubsection{Sources of data on labor force participation rates}

ILO LABORSTAT and ILO KILM online websites provide data on labor force participation rates by age and sex for almost every country in the world. The main problem with these data for estimating a living wage is that they are national rates and not the rural and urban rates required. For this reason, researchers should try to find rural and urban rates from national sources such as censuses, labor force surveys, demographic surveys, and household surveys. Note that researchers always need to keep in mind that judgment is necessary when multiple data sources are available because labor force participation rates often differ between surveys for various reasons such as ones discussed above.

\subsection{Unemployment Rate (Absence of Work)}

\subsubsection{Definition of unemployment rate}

Unemployment rate is calculated by dividing the number of unemployed persons by the number of persons in the labor force (that includes unemployed persons). For a person to be considered unemployed according to the international definition of unemployment, s/he needs to be: above a specified age, without any work in the reference period (even 1 hour of work in the past week is considered as being employed), available for work in the reference period, and actively seeking work in the reference period (ILO, 1982).

Unemployment rates are necessarily sensitive to how questions are asked on labor force surveys and household surveys, since the definition of unemployment is partly subjective. It is not clear, for example, what constitutes actively looking for work (or its meaning) in locations where few if any jobs are available. Indeed, many people without work do not actively look for 
work in locations with few if any job opportunities, since there is no reason to actively look for work in such locations. As a result, such people are considered to be outside of the labor force and not unemployed.

\subsubsection{Unemployment rates usually lower in rural areas than in urban areas in developing countries}

Unemployment rates are generally lower in rural areas than in urban areas in developing countries. One reason is that many people in rural areas who are without work do not actively look for work (one criterion in the definition of unemployment) because it would be fruitless to look for work when very few jobs are available. Another reason why unemployment rates are generally lower in rural areas compared with urban areas in developing countries is that many people in rural areas work on a family farm or with family animals and so are considered to be labor force participants even when this work is done for only an hour or two each day.

In light of the above discussion, it is important to identify and use separate unemployment rates for rural and urban areas whenever possible.

\subsubsection{Unemployment rates higher for youth}

Youth unemployment rates are much higher than adult unemployment rates throughout the world (Table 13.2). Youth unemployment rate is 2.8 times the adult unemployment rate for the world as a whole and is higher than the adult unemployment rate in all regions of the world. The ratio of youth unemployment rate to adult unemployment rate ranges from around 2 in Sub-Sahara Africa; to around 5 in South-East Asia and Pacific. Youths are in a better position than adults to be able to 'afford' to be unemployed, in part because they can continue to live with their parents. Educated youth unemployment is especially high, because many educated youths come from wealthier families.

Unemployment rate to estimate a living wage should be based on ages 25-59 when possible. It is important to exclude youths (ages 15-24) when estimating unemployment rates for a living wage.

\subsubsection{Sources of data on unemployment rates}

It is usually advisable to find several unemployment rate estimates including estimates by age and for rural and urban areas. First, unemployment rates often differ by survey and source partly because of the subjectivity of how unemployment is defined and measured and partly because unemployment rates reported by governments are sometimes influenced by political considerations. Second, rural and urban unemployment rates always differ, and only national unemployment rates are available from international sources. Third, available unemployment rates are not always 
Table 13.2 Youth and adult unemployment rates by region of the world, 2012

\begin{tabular}{lccc}
\hline Region & $\begin{array}{c}\text { Youth } \\
\text { unemployment } \\
\text { rate (ages 15-24) }\end{array}$ & $\begin{array}{c}\text { Adult } \\
\text { unemployment } \\
\text { rate (ages 25+) }\end{array}$ & $\begin{array}{c}\text { Ratio youth/adult } \\
\text { unemployment } \\
\text { rates }\end{array}$ \\
\hline World & 12.6 & 4.5 & 2.8 \\
Developed Economies \& & 17.9 & 7.3 & 2.4 \\
$\quad$ Europe & 17.1 & 6.9 & 2.5 \\
Central \& South-East & & & \\
$\quad$ Europe & 9.5 & 3.5 & 2.7 \\
East Asia & 13.0 & 2.5 & 5.2 \\
South-East Asia \& Pacific & 9.8 & 2.3 & 4.2 \\
South Asia & 13.5 & 4.9 & 2.7 \\
Latin America \& Caribbean & 28.1 & 7.5 & 3.8 \\
Middle East & 23.8 & 7.1 & 3.3 \\
North Africa & 11.9 & 6.2 & 2.0 \\
Sub-Sahara Africa & & & \\
\hline
\end{tabular}

Notes: Youth defined as ages $15-24$ and adults as ages $25+$ in source.

Source: ILO KILM, 2013a.

recent and unemployment rates are sensitive to economic conditions that change year by year and month by month. It is also advisable to use national sources whenever possible because they are more likely to be upto-date than international sources. ${ }^{2}$

Because unemployment rates differ by source, geographic coverage, age group, and year, judgment is often required before using them to estimate a living wage. For example, in the Dominican Republic while we found a recent national unemployment rate, we were unable to find recent rural and urban unemployment rates. But since we found rural and urban unemployment rates for an earlier year, we applied the ratio of rural to urban unemployment rates from this earlier year to the recent national unemployment rate to estimate recent rural and urban rates. In Kenya, judgment was required because there were no official government unemployment rates and the unemployment rates we found ranged from $17-40 \%$ and came from 1999 to 2010 . This meant that we needed to consider the credibility of each source and how recent it was. In China, official unemployment rates are based on a registration system that is known to understate unemployment. The official urban unemployment rate was $4.1 \%$ for 2014 . A national household survey found that the unemployment rate averaged 10.9\% between 2002 and 2009 (Feng et al., 2015). Chinese researchers 
decided to use this unemployment rate of $10.9 \%$ for their living wage estimate as they judged it to be more realistic.

\subsection{Part-time Employment and Less than Full-time Work over the Year}

The internationally accepted definition of labor force participation is binary. People are either in the labor force or out of the labor force without any consideration of how many hours they work. Someone who works one hour per week is counted the same as someone who works 50 hours per week. And depending on when a labor force survey is conducted, someone who works only in peak seasons is counted the same as someone who works year-round. This creates problems for estimating a living wage, since we are interested in the number of full-time equivalent workers per family over the year. It is for this reason that it is necessary to take part-time employment into consideration.

There is no internationally accepted definition of part-time employment, which makes it problematic to use data on part-time employment rates without careful thought. Preferable are data on the distribution of hours worked, because these data allow researchers to calculate the percentage of workers who work less than a specific cut-off such as 20 or 30 hours per week.

\subsubsection{Sources of data on part-time employment and hours of work}

It is worth looking to see if data are available from government websites and publications and from academic publications. National data on parttime employment or the distribution of number of hours worked are often available. ${ }^{3}$ But, unfortunately, when data on part-time employment are available, they are often only available for the entire country - yet part-time employment rates differ greatly for rural and urban areas within countries as well as for men and women. This means that for many countries, it is necessary to rely partly on discussions with workers and key informants about the extensiveness of part-time work for rural and urban areas and for male and female workers. In such discussions, it is important to keep in mind that there are two distinct types of less than full-time work over the year - work that is always part-time (e.g. urban part-time job or caring for family-owned animals) and full-time work that is done only in certain seasons (e.g. peak season farm work). Our experience is that part-time wage jobs are often uncommon in developing countries but that work in rural areas is often part-time and often seasonal. When data are not available on part-time employment or hours of work and discussions with workers and key informants indicate that there is not much part-time employment, we suggest using a 5\% part-time employment rate for urban settings as a practical and reasonable assumption. 


\subsection{Equations to Estimate Number of Full-time Equivalent Workers per Family}

Estimating the number of full-time equivalent workers per family begins with two assumptions.

1. One member of the family is assumed to be a full-time worker yearround. This assumption is used because a living wage is concerned with a situation in which at least one adult worker in the reference family is working.

2. Part-time work is assumed to be half-time work. This assumption is made for reasons of practicality when data on hours of work are not available.

Two equations are used to estimate the number of full-time equivalent workers per family to help estimate a living wage. Equation 1 estimates the typical proportion of full-time equivalent work per working age adult in the general population. Equation 2 estimates the number of full-time equivalent workers per reference family.

\subsubsection{Equation 1: Proportion of full-time equivalent work per working age adult in the general population}

Proportion of full-time equivalent work per working age adult $=$ Average adult LFPR $\times(1$ - unemployment rate $) \times(1-$ [part-time employment rate $\div 2$ ])

Where:

LFPR (labor force participation rate) measures the probability that an adult age $25-59$ is economically active.

1 - unemployment rate for ages 25-59 measures probability that someone in the labor force is able to find work.

1 - [part-time employment rate $\div 2$ ] measures extent to which someone with work is working full-time using simplifying assumption that part-time employment is half-time.

\subsubsection{Equation 2: Number of full-time equivalent workers per family}

Number of full-time equivalent workers per family $=1+$ proportion of full-time work per working age adult calculated in equation 1 
These equations are based on the assumption that one adult in the family has full-time work year-round, and that the amount of work done by the second adult is the proportion of full-time work of adults aged 25-59 in the general population. The reason for assuming one full-time worker in a family is that most companies, governments, NGOs, unions and laypersons are concerned with workers who are employed full-time and year-round.

\subsubsection{Implication of the assumption that one family member is a full- time worker year-round}

There are several important implications of assuming one full-time worker in the reference family. First, it implies that living wage estimates are not relevant for part-time workers, and it is not appropriate to convert a monthly living wage into an hourly or daily living wage for part-time workers. The lack of equivalency between living wage per hour or per day and living wage per month comes about because part-time workers do not work a sufficient number of hours to enable them to earn enough to support their family at a decent living standard. Minimum wage laws for Shenzhen and Chengdu, China, provide examples of this lack of equivalency for hourly (CNY18.5 and CNY14.6) and monthly minimum wages (CNY2,030 and CNY1,500) as the hourly minimum wage is $58 \%$ and $69 \%$ higher respectively than the hourly value of the monthly minimum wage in these two cities. Second, this assumption means that when permanent workers are not provided full-time work throughout the year, it is necessary to adjust for this. We saw this situation in rural Malawi where permanent tea plantations workers were offered 23 days of work per month on average over the year rather than 26 days of full-time work because of low yields of tea bushes during the slack season. Not offering full-time work throughout the year to permanent workers is also common in factories where demand is seasonal such as being high say around Christmas and low during the summer.

\subsubsection{Likely range for number of full-time equivalent workers per family}

Table 13.3 provides results on how the number of full-time equivalent workers per couple was estimated in five living wage studies carried out for Global Living Wage Coalition members. The range of values is fairly small for these five studies, only ranging from 1.58 to 1.78 , despite very different labor market conditions in these five countries. Rural Malawi has a very high labor force participation rate (96\% for ages $25-59)$. But rural Malawi has a very high rate of part-time employment over the year due to the importance of a rain-fed small farm sector, which pulls down the estimated number of full-time equivalent workers for rural Malawi. South Africa Cape Winelands and rural Dominican Republic have lower labor force participation rates (78\% and $77 \%$ respectively) and Bangladesh has 
Table 13.3 Calculation of number of full-time workers per family in five countries

\begin{tabular}{|c|c|c|c|c|c|}
\hline Factors & $\begin{array}{l}\text { Malawi } \\
\text { (rural) }\end{array}$ & $\begin{array}{l}\text { Bangladesh } \\
\text { (urban) }\end{array}$ & $\begin{array}{c}\text { South } \\
\text { Africa (Cape } \\
\text { Winelands) }\end{array}$ & $\begin{array}{l}\text { Dominican } \\
\text { Republic } \\
\text { (rural) }\end{array}$ & $\begin{array}{c}\text { China } \\
\text { (Shenzhen) }\end{array}$ \\
\hline $\begin{array}{l}\text { Labor force } \\
\text { participation } \\
\text { rate ages } 25-59\end{array}$ & $96.0 \%$ & $66.0 \%$ & $77.5 \%$ & $76.8 \%$ & $89.2 \%$ \\
\hline $\begin{array}{l}\text { Unemployment rate } \\
\text { ages } 25-59\end{array}$ & $3.0 \%$ & $4.7 \%$ & $17.0 \%$ & $8.6 \%$ & $10.8 \%$ \\
\hline $\begin{array}{l}\text { Part-time } \\
\text { employment rate }\end{array}$ & $\begin{array}{l}63 \% \text { full- } \\
\text { time hours }\end{array}$ & $18.2 \%$ & $4.6 \%$ & $5.3 \%$ & $5.0 \%$ \\
\hline $\begin{array}{l}\text { Number of full- } \\
\text { time equivalent } \\
\text { workers per } \\
\text { family }\end{array}$ & 1.59 & 1.58 & 1.63 & 1.67 & 1.78 \\
\hline
\end{tabular}

Source: Anker and Anker, 2014a, 2013, and 2013a and unpublished living wage reports for Bangladesh and China.

a much lower labor force participation rate (66\%) than rural Malawi, but they also have lower part-time employment rates compared with Malawi. China (Shenzhen) has the highest estimated number of full-time workers per couple of the countries included in Table 13.3, because it has very high labor force participation rates for both women and men and low part-time employment rates, although it has a somewhat high urban unemployment rate of $10.9 \%$ according to national survey data. If the $4.1 \%$ official unemployment rate for Shenzhen had been used, which is based on an unemployment registration system that is known to undercount unemployment, there would have been 1.83 full-time workers per couple, which would represent a situation where labor force participation rates are very high for both women and men, and unemployment rates and part-time employment rates are both very low.

\section{PART III. EXAMPLE}

\subsection{Number of Workers per Family: A Hypothetical Example}

\subsubsection{Labor force participation rate (LFPR)}

Labor force participation rate for ages $25-59$ is around $80 \%$, according to recent household surveys. 


\subsubsection{Unemployment rate (U)}

Open unemployment is not common in the area. For persons ages 25-59, it was $1.9 \%$ according to a recent population census and around $4 \%$ according to a recent household survey. It is not unusual to find different unemployment rates from different sources, and it is necessary to evaluate the credibility of the sources and the year in which they were executed. In this case, both sources were considered credible, and their unemployment rates were not very far apart. We split the difference and used 3\%.

\subsubsection{Part-time employment (PT)}

Part-time employment rate is $15 \%, 5 \%$ for men and $25 \%$ for women.

\subsubsection{Calculation of number of full-time equivalent workers per family}

Based on the below discussion, we substituted the following values in equations 1 and 2 below to get the number of full-time equivalent workers per family:

- Labor force participation rate $=.80$

- Unemployment rate $=.03$

- Proportion of full-time work $=.15$

\section{Equation 1:}

Proportion of full-time work per adult $=(.80$ LFPR $) \times(1-.03 U) \times$ $(1-.15 P T \div 2)=0.72$

\section{Equation 2:}

Number of full-time equivalent workers per family $=1$ worker $+0.72=1.72$ full-time equivalent workers per couple

\section{NOTES}

1. Male labor force participation rates for ages $25+$ are approximately $84 \%$ for the world. Rates are lower for Developed Economies and Europe (71\%) and Central and Eastern Europe $(76 \%)$ where school attendance often extends beyond age 25 , social assistance facilitates withdrawal from the labor force, and retirement benefits allow early retirement.

2. ILO KILM and ILO LABORSTAT websites indicate national unemployment rates by age based on information provided to ILO by national authorities. ILO KILM tabulates and presents unemployment rates for ages 15-24 and ages $25+$. The main problem with ILO unemployment rate data for estimating a living wage is that they are national values - but separate rural and urban values should be used to estimate a living wage.

3. ILO LABORSTAT and ILO KILM provide data on hours of work for some countries. Most of these are drawn from an OECD database and usually only cover formal sector employment. 


\section{APPENDIX 13.1 SECONDARY DATA ON LABOR FORCE PARTICIPATION, UNEMPLOYMENT AND PART- TIME EMPLOYMENT USED TO DETERMINE THE NUMBER OF FULL-TIME EQUIVALENT WORKERS PER FAMILY}

Our living wage methodology assumes that more than one family member works and provides financial support for the family. To estimate a typical number of full-time equivalent workers per couple, secondary data are required on labor force participation rates, unemployment rates, and parttime employment rates for persons aged 25-59.

The available secondary data for the location of interest (e.g. rural or urban) should be indicated in the tables below. Since values for these variables are sensitive to how they are defined and measured and how recently they were measured, it is useful to collect information on these from several sources and years.

\section{Labor Force Participation Rate from Secondary Data Sources}

Information on labor force participation rates by five-year age groups, sex and location of interest should be recorded in Table 13A.1. With this information, it is possible to calculate the average labor force participation rate for ages 25-59. Separate copies of Table 13A.1 should be used for additional data sources and/or years.

\section{Unemployment Rate from Secondary Data Sources}

Information on unemployment rates by five-year age groups, sex and location of interest (e.g. rural/urban/national) should be recorded in Table 13A.2. With this information, it is possible to calculate the average labor force participation rate for ages 25-59. Note that separate copies of Table 13A.2 should be used for additional data sources and/or years.

\section{Part-time Employment Rate from Secondary Sources}

The part-time employment rate is the proportion of workers who work part-time - often defined as \% of workers who work less than 20 or 30 hours per week. 
Table 13A.1 Labor force participation rates (LFPRs) by age, sex and location

\begin{tabular}{|c|c|c|c|c|c|c|c|c|c|}
\hline $\begin{array}{l}\text { Source } \\
\text { and year }\end{array}$ & \multicolumn{3}{|c|}{ Rural } & \multicolumn{3}{|c|}{ Urban } & \multicolumn{3}{|c|}{ National } \\
\hline Age group & M & $\mathrm{F}$ & All & M & $\mathrm{F}$ & All & M & $\mathrm{F}$ & All \\
\hline $15-19$ & & & & & & & & & \\
\hline $20-24$ & & & & & & & & & \\
\hline $25-29$ & & & & & & & & & \\
\hline $30-34$ & & & & & & & & & \\
\hline $35-39$ & & & & & & & & & \\
\hline $40-44$ & & & & & & & & & \\
\hline $45-49$ & & & & & & & & & \\
\hline $50-54$ & & & & & & & & & \\
\hline $55-59$ & & & & & & & & & \\
\hline $\begin{array}{l}\text { Calculate } \\
\quad \text { average 25-59a }\end{array}$ & & & & & & & & & \\
\hline
\end{tabular}

Note: ${ }^{a}$ It is easiest to estimate this by summing age specific labor force participation rates for ages $25-59$ and dividing this sum by 7 . This creates a synthetic measure of labor force participation rate for ages 25-59. Alternatively, when data on population and number of workers for ages 25-59 are available, a labor force participation rate for ages $25-59$ can be estimated by dividing the number of labor force participants ages $25-59$ by the population age $25-59$.

Table 13A.2 Unemployment rates by age and location

\begin{tabular}{|l|c|c|c|c|c|c|c|c|c|}
\hline \multirow{2}{*}{$\begin{array}{l}\text { Source } \\
\text { and year }\end{array}$} & \multicolumn{3}{|c|}{ Rural } & \multicolumn{3}{c|}{ Urban } & \multicolumn{3}{c|}{ National } \\
\hline & \multicolumn{3}{|c|}{ M } & \multicolumn{3}{c|}{} & \multicolumn{3}{c|}{} \\
\hline Age group & M & F & All & M & F & All & M & F & All \\
\hline $15-19$ & & & & & & & & & \\
\hline $20-24$ & & & & & & & & & \\
\hline $25-29$ & & & & & & & & & \\
\hline $30-34$ & & & & & & & & & \\
\hline $35-39$ & & & & & & & & & \\
\hline $40-44$ & & & & & & & & & \\
\hline $45-49$ & & & & & & & & & \\
\hline $50-54$ & & & & & & & & & \\
\hline $55-59$ & & & & & & & & & \\
\hline $\begin{array}{c}\text { Calculate } \\
\text { average 25-59 }\end{array}$ & & & & & & & & \\
\hline
\end{tabular}


Table 13A.3 Part-time employment rate by location

\begin{tabular}{|l|l|l|l|l|l|}
\hline Source & Year & Rural & Urban & National & Definition used by source \\
\hline & & & & & \\
\hline & & & & & \\
\hline & & & & & \\
\hline & & & & & \\
\hline
\end{tabular}

Table 13A.4 Summary table for labor force variables

\begin{tabular}{|c|c|c|c|c|c|c|}
\hline \multicolumn{7}{|l|}{ LFPR } \\
\hline Source & Year & $\begin{array}{l}\text { Age } \\
\text { group }\end{array}$ & Rural & Urban & National & Comments \\
\hline \multicolumn{7}{|l|}{$\begin{array}{l}\text { Conclusion for } \\
\text { LFPR }\end{array}$} \\
\hline \multicolumn{7}{|l|}{$\begin{array}{l}\text { Justification for } \\
\text { conclusion }\end{array}$} \\
\hline \multicolumn{7}{|l|}{ Unemployment rate } \\
\hline Source & Year & $\begin{array}{l}\text { Age } \\
\text { group }\end{array}$ & Rural & Urban & National & Comments \\
\hline \multicolumn{7}{|l|}{$\begin{array}{l}\text { Conclusion for } \\
\text { unemployment } \\
\text { rate }\end{array}$} \\
\hline \multicolumn{7}{|l|}{$\begin{array}{l}\text { Justification for } \\
\text { conclusion }\end{array}$} \\
\hline \multicolumn{7}{|c|}{ Part-time employment rate } \\
\hline Source & Year & Rural & Urban & National & $\begin{array}{l}\text { Definition } \\
\text { used }\end{array}$ & Comments \\
\hline \multicolumn{7}{|l|}{$\begin{array}{l}\text { Conclusion } \\
\text { for part-time } \\
\text { employment rate }\end{array}$} \\
\hline $\begin{array}{l}\text { Justification for } \\
\text { conclusion }\end{array}$ & & & & & & \\
\hline
\end{tabular}




\section{Table for Summarizing Data and Decisions on Labor Force Participation Rate, Unemployment Rate and Part-time Employment Rate}

Table 13A.4 provides a dummy table for summarizing results and decisions from Tables 13A.1 to 13A.3. Space is provided to record conclusions and justifications about which rates are most suitable for estimating number of full-time equivalent workers per reference family. 